\title{
Study of regional geological structures in Ridi-Shantipur area of Gulmi district, Lesser Himalaya, west-central Nepal
}

\author{
*Shrawan Shakya ${ }^{1}$ and Kabi Raj Paudyal ${ }^{2}$ \\ ${ }^{1}$ Groundwater Resource Development Board, Babarmahal, Kathmandu, Nepal \\ ${ }^{2}$ Central Department of Geology, Tribhuvan University, Kirtipur, Kathmandu, Nepal \\ *Corresponding author: shrawan2011@outlook.com
}

\begin{abstract}
The study was carried out in the Lesser Himalaya between Ridi-Shantipur area of the Gulmi District, west-central Nepal. Two geological units: the Nourpul Formation and the Dhading Dolomite were mapped in the area. These units belong to the Nawakot Group as explained by several researchers in central Nepal. The Nourpul Formation can further be divided into three members based on distinct mappable lithology, which are named as the Lower Member, the Middle Member and the Upper Member, respectively.

The area is highly folded with several local and regional anticlines and synclines; Ridi Khola Anticline, Ridi-Karikot Syncline, Ruru Anticline, Baletaksar-Gwadi Syncline, Huga-Bamgha Anticline, Rimuwa-Rudrabeni Syncline, Juhan-Eksing Anticline, Juniya-Limgha Syncline, Bharse-Thaple Anticline, and Chiureko Syncline, respectively from the south to the north. All the folds are trending along to the ESE-WNW direction. The origin of these folds can be linked with the thrust propagation in the Himalaya that can be explained with the deformation event D4.

The Harewa Khola Thrust is the only one regional scale thrust mapped in the area. The thrust carries the older Nourpul Formation over the Dhading Dolomite with the indications of thrust related features like slickensides and fault-breccias. The thrust seems to propagate to the north. There is a continuous shear zone mapped in the outcrops from the Tal Khola-Aslewa-Eksingh-Gudrung-JuhangRupakot region as an indicator of the presence of the Badi Gad Fault in the region..
\end{abstract}

Keywords: Geological structures, Deformation event, Harewa Khola Thrust, Badi Gad Fault, Lesser Himalaya

Paper Received: 30 Dec 2018

Paper Accepted: 20 Mar 2019

\section{INTRODUCTION}

The Himalayas is the youngest and the highest mountain ranges in the world. It is about $2400 \mathrm{~km}$ in length. The Himalaya is believed to be originated as a result of continent-continent collision between Indian and Eurasia Plates (Dewey and Bird, 1970; Powell and Conaghan, 1973). India-Eurasia collision caused slicing of the northern margin of the Indian continent into three blocks along three principal thrusts: the Main Central Thrust (MCT), the Main Boundary Thrust (MBT) and the Main (or Himalayan) Frontal Thrust (MFT). These major intra-crustal thrusts divide the Himalaya into four tectonic zones as the SubHimalaya, the Lesser Himalaya, the Higher Himalaya, and the Tethys Himalaya from south to north, respectively (Gansser, 1964). The Lesser Himalaya represents a fold-and-thrust belt in the region. Many works have been carried out in the past in the Lesser Himalaya such as the Nawakot Group in central Nepal (Stöcklin and Bhattarai, 1977; Stöcklin, 1980), Kali Gandaki Supergroup in west-central Nepal (Sakai, 1983; 1985), Dang-Sallayan area in the west (Dhital and Kizaki, 1987a and 1987b), Syangja area in the west (Dhital et al., 2002), Muglin area in west-central Nepal (Paudyal and Paudel, 2011a, 2011b and 2013), and Muglin-Bandipur area west-central Nepal (Paudyal, 2012).
Active faults in the Nepal Himalayas are mainly distributed along the major tectonic lines as well as older geological faults in the Lesser Himalaya (Nakata, 1982; Nakata et al., 1984). The Badi Gad Fault (Nakata et al., 1984) is one of the Central Active Fault System in the Lesser Himalaya. The present work is mainly focused concerning the geology and regional structure of Ridi-Shantipur area, west-central Nepal. The study area covers major parts of the Gulmi District and small parts of the Syangja and the Palpa Districts of west-central Nepal (Fig. 1). The study area lies between the latitudes of $3089000 \mathrm{~N}$ and $3112000 \mathrm{~N}\left(27^{0} 55^{\prime} 00^{\prime \prime}-28^{\circ} 07^{\prime} 30^{\prime \prime}\right)$ and longitudes between $039000 \mathrm{E}$ and $053000 \mathrm{E}\left(83^{0} 22^{\prime} 30^{\prime \prime}-83^{0} 32^{\prime} 30^{\prime \prime}\right)$. Present study covers an area of about $250 \mathrm{sq}$. km. The famous places of the area are Ridi Bazar, Rudrabeni Gaun, Khaireni Bazar, and Shantipur village. Similarly, the major rivers are the Kali Gandaki and the Badi Gad Khola.

Nakata (1982) and Nakata et al. (1984) carried out the geological study in the northern region of the present area focusing to the Badi Gad Fault, used aerial photos to interpret the extension of the Badi Gad Fault, and noticed several river course diversions and terraces tilting as the indicator of the Badi Gad Fault. However, the present area was not investigated in terms of mapping of geological structures. Therefore, the main 


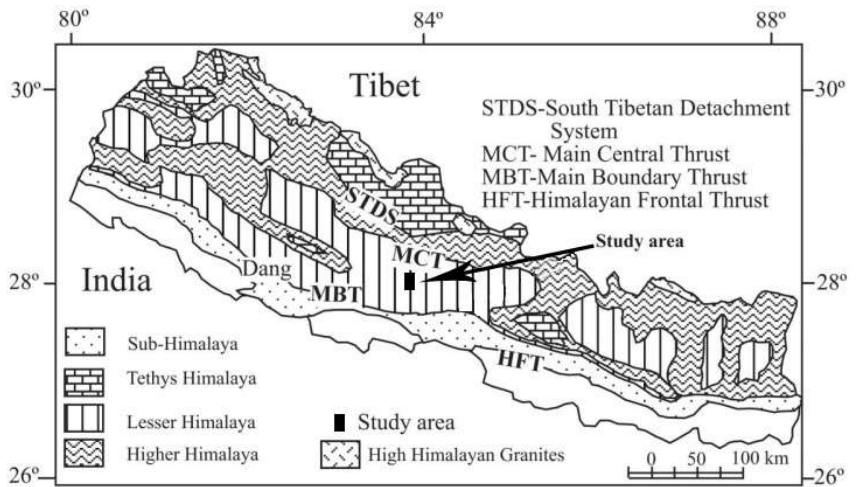

Fig. 1: Simplified geological map of the Nepal Himalaya showing the study area (modified after Upreti and Le Fort, 1999)

objective of the study was to prepare a geological map and cross-sections in 1:25,000-scales to investigate the regional geological structures in the Ridi-Shantipur area.

\section{MATERIALS AND METHODS}

Topographical map (sheet no. 2783 02B, 1999 and sheet no. 2883 14D, 1998 in 1:25000 scale) published by the Department of Survey, Government of Nepal were used for the geological mapping. The major previous publication includes the Geological maps by the Department of Mines and Geology (DMG) in 1983 and 2000 (Tater et al., 1983; Shrestha et al., 2000) and structural map of Sako et al. (1973). During the mapping of regional geological structures, outcrop scale geological structures were measured and documented. The regional geological map was prepared in a team of nine thesis students of Central Department of Geology, Tribhuvan University (Batch: 2014/15) lead by the second author of this paper as supervisor. Out of several objectives, one of the focuses was given to map the presence and extension of the Badi Gad Fault in the region. Mapping was carried out with specific objective to each student. Accordingly, the detail investigation of the Badi Gad Fault was carried out by Timalsina (Timalsina and Paudyal, 2018). Two major routes (i) Argelli-Ridi section and the (ii) Ridi-Rudrabeni section were selected for detail route mapping.

Stratigraphy was worked out preparing columnar sections and chronological relation of the strata was established with the help of sedimentary structures such as ripple marks, crosslaminations and stromatolites. Emphasis was given to locate and measure both local as well as regional geological structures. Structural components like attitudes of beds and foliation, trend of fold axis and lineation, extension of fault lines, etc. were documented in the field. Geological contacts and representative cross-sections were drawn in the field. Representative samples of the rocks and photographs of important geological features were taken from the field.

\section{RESULTS}

\section{Geology and Stratigraphy of Ridi-Shantipur area}

The study area includes four major rivers, i.e., the Kali Gandaki River in the north-west, the north portion of the Ridi Khola, south-east portion of the Hugdi Khola and north-the south segment of the Badi Gad Khola. The study area is characterized by the presence of low-grade metamorphic rocks like slates, phyllites, quartzites and metasandstones. Only the rocks of the Nourpul Formation and the Dhading Dolomite of the Nawakot Group are exposed in the area (Figs. 2 and 3). The geological contact between these units can be seen frequently in several areas. The repetition of the geological units is observed due to intense folding of the strata in the region.

\section{Nourpul Formation}

The Nourpul Formation is widely distributed in the region with its major occurrence towards the south of the Badi Gad River (Figs. 2 and 3). In the present study, the Nourpul Formation is divisible into three members based on distinct lithology. They are the Lower Member, the Middle Member and the Upper Member, successively from the bottom to the top (Figs. 2, 3 and 4). The Lower Member is predominantly of thin- to medium-bedded, fine- to medium-grained, grey phyllite with subordinate proportion of grey, thin-bedded metasandstone. The most remarkable feature is that the phyllite is foliated and calcareous in nature. The Middle Member predominantly consists of thick- bedded, medium-grained, grey siliceous stromatolite containing dolomites with varying proportion of thick-bedded, medium- to coarse-grained, grey metasandstone (arenite) and medium-bedded, fine- to mediumgrained grey psammatic phyllite. This succession is stratigraphically followed by beds of thin- to medium-bedded grey, psammatic phyllite and medium-bedded, grey metasandstone with current and linguoid ripple marks (Fig. 5). The Upper Member consists dominantly of metasandstone, which makes it different from the Lower Member. The Dhading Dolomite sharply overlies the Nourpul Formation. The total thickness of the Nourpul Formation in the area is about $1 \mathrm{~km}$.

\section{Dhading Dolomite}

This geological unit consists of monotonous succession of grey, medium- to thick-bedded, siliceous dolomite with minor amounts of phyllite. The dolomite consists of well-developed algal mats and stromatolites (Fig. 6). Domal shaped stromatolites show that the rock succession is right side up, i.e. normal setting. Another remarkable feature in this dolomite is the presence of intra-formational clasts (30-150 mm in length) (Fig. 7). The thickness of the Dhading Dolomite unit is about $150 \mathrm{~m}$ in the region. 


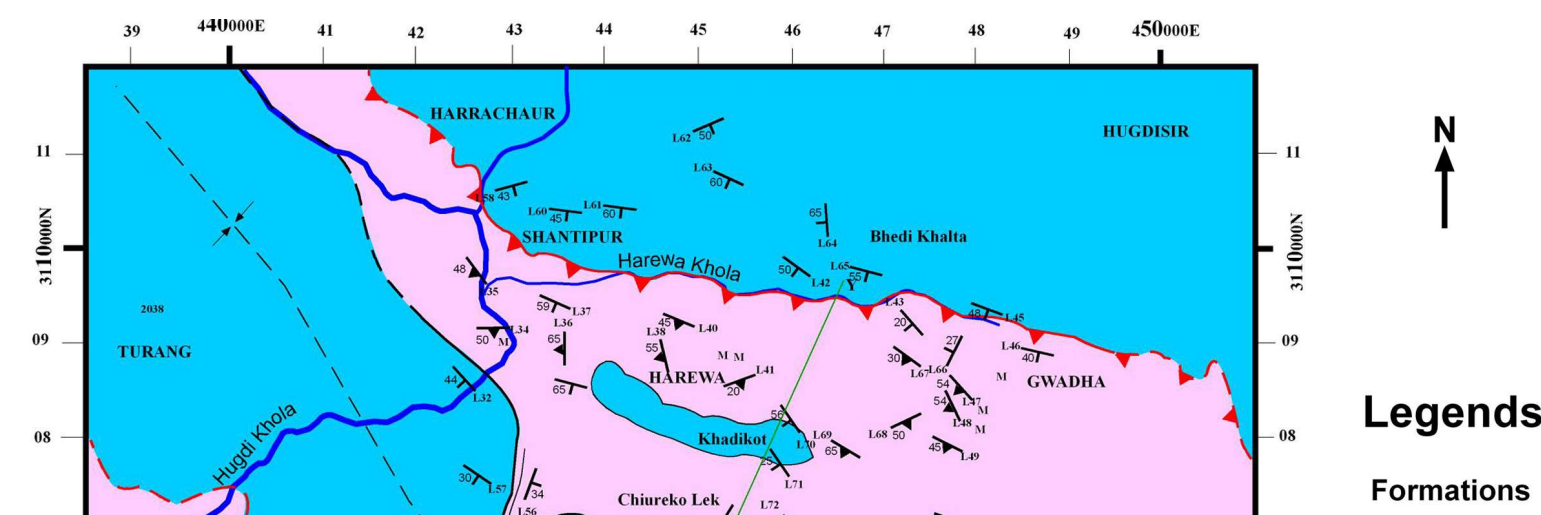

\section{Formations}

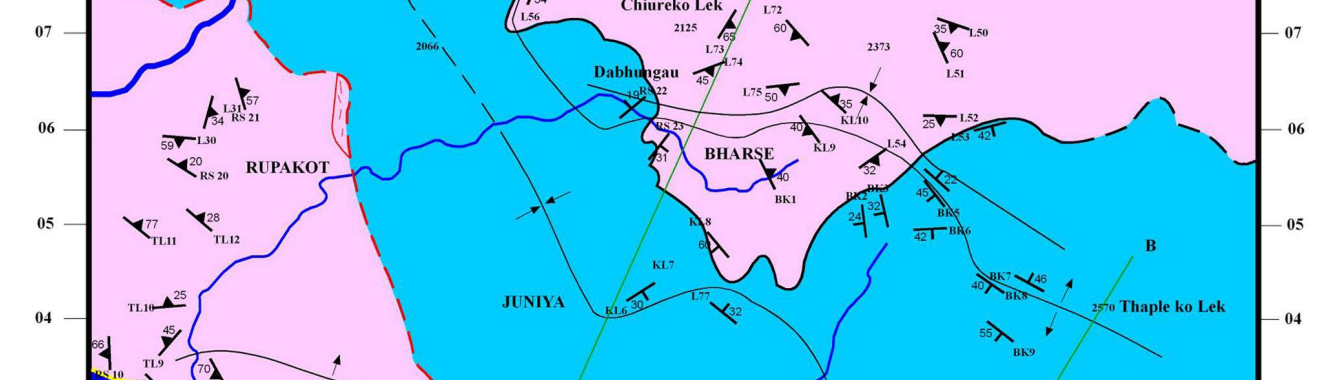

Dhading Dolomite

Nourpul Formation

$\square$ Upper Member

Middle Member

$\square$ Lower Member

$\times^{30}$ Attitude of bed

$x^{30}$ Attitude of foliation

$\checkmark$ Geological contact

- - Inferred geological

Xynclinal axis

$\star$ Anticlinal axis

_. Thrust Contact

$\longrightarrow$ Fault

S=- Shear zone

Road

$T$ Drainage

$X-Y$ Cross section

A B B Lines

2570 Spot height

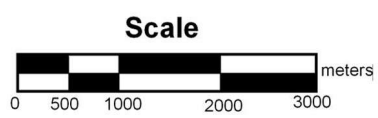

Fig. 2: Geological map of the Ridi-Shantipur area 


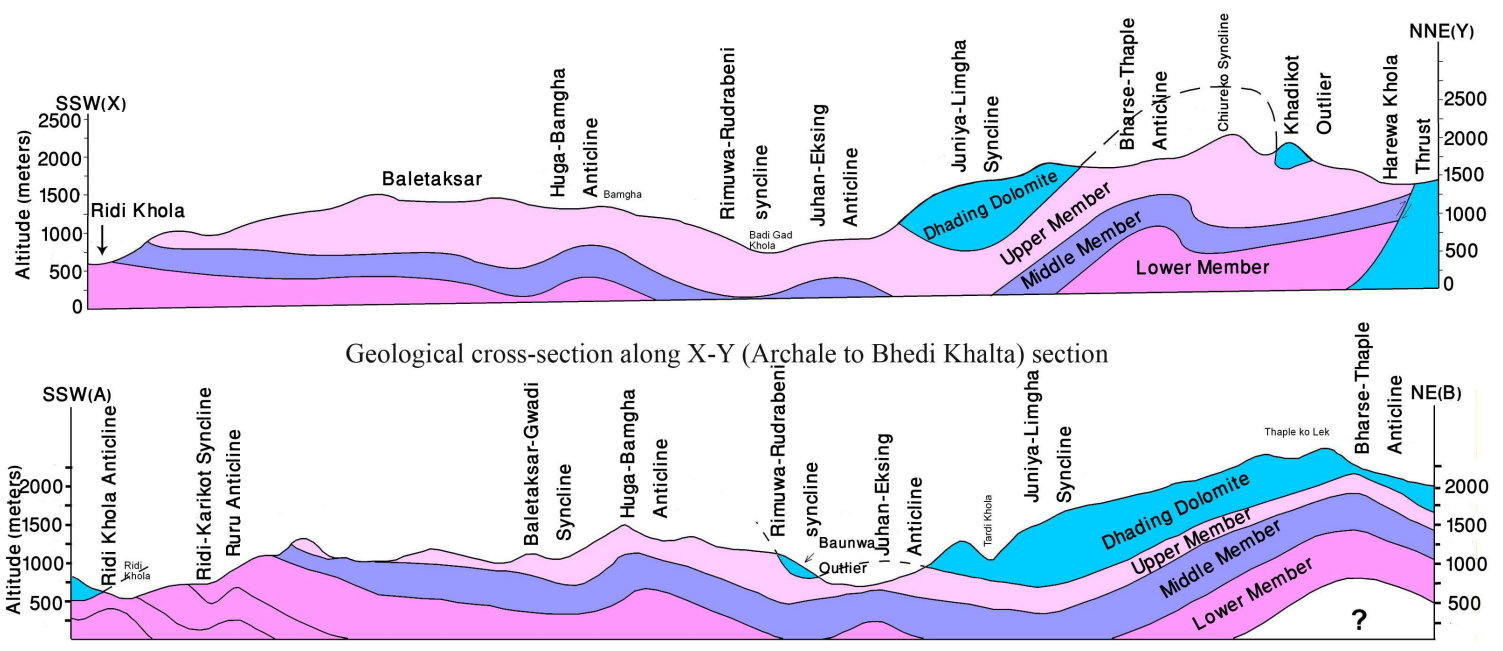

Geological cross-section along A-B (Jogithum to Thaple ko Lek) section

Fig. 3: Geological cross-section along X-Y and A-B from Fig. 2

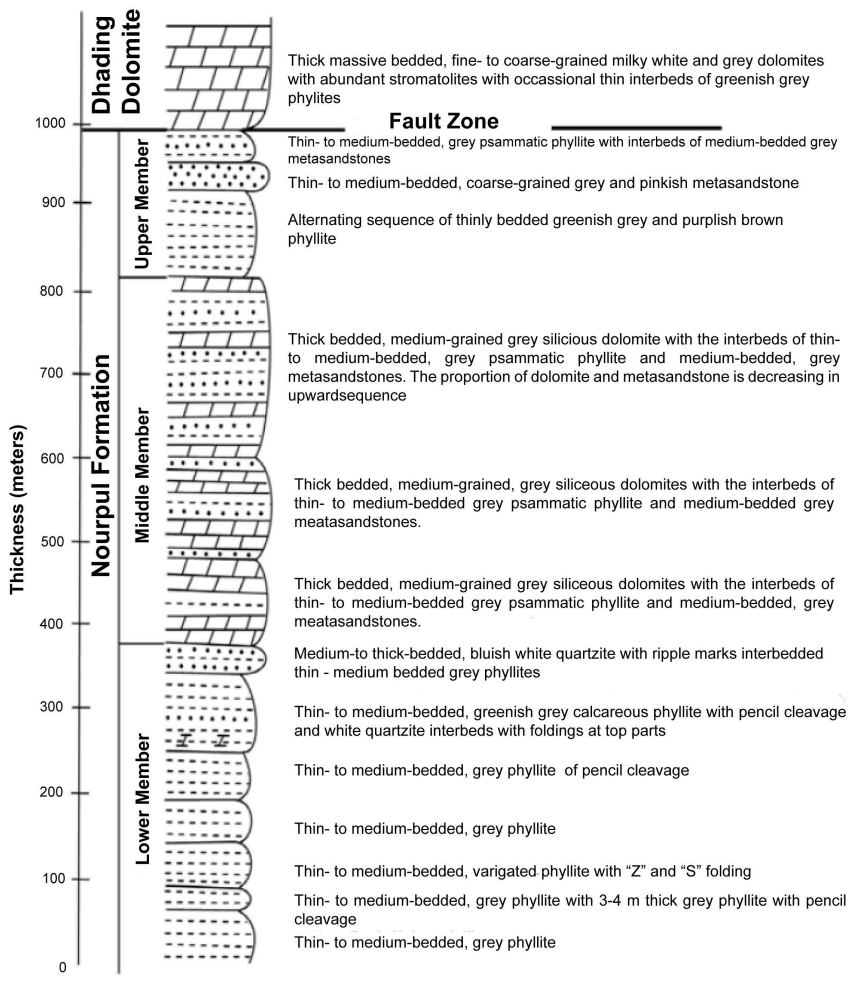

Fig. 4: Generalized columnar section of the rocks exposed in Ridi-Shantipur area

\section{Regional Geological Structures}

\section{Folds}

The area has undergone intense deformation forming a number of regional scale folds. Such folds are mainly observed in the Dhading Dolomite and the Nourpul Formation of the

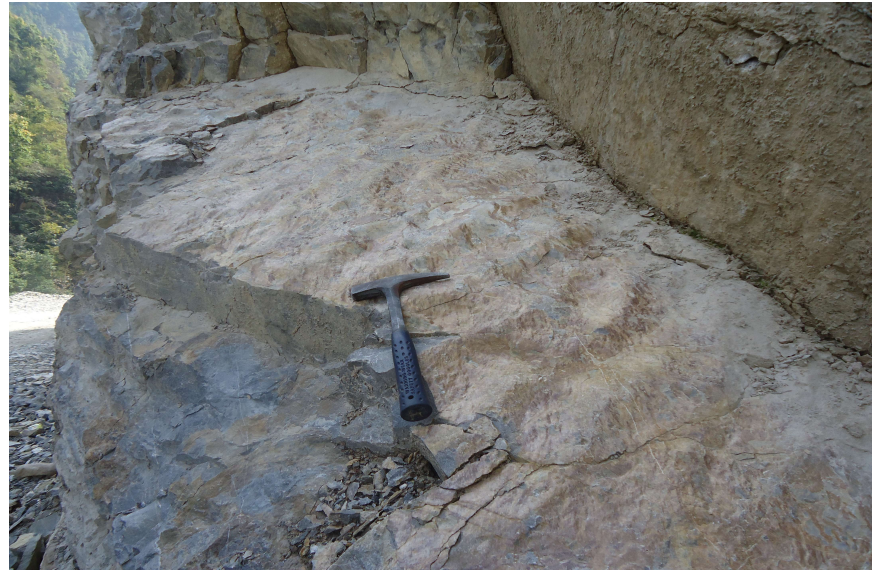

Fig.5: Lingoidal ripple marks observed in metasandstones of the Middle Member of the Nourpul Formation, about 3 km NE from Ridi Bazar towards Rudrabeni along the road section

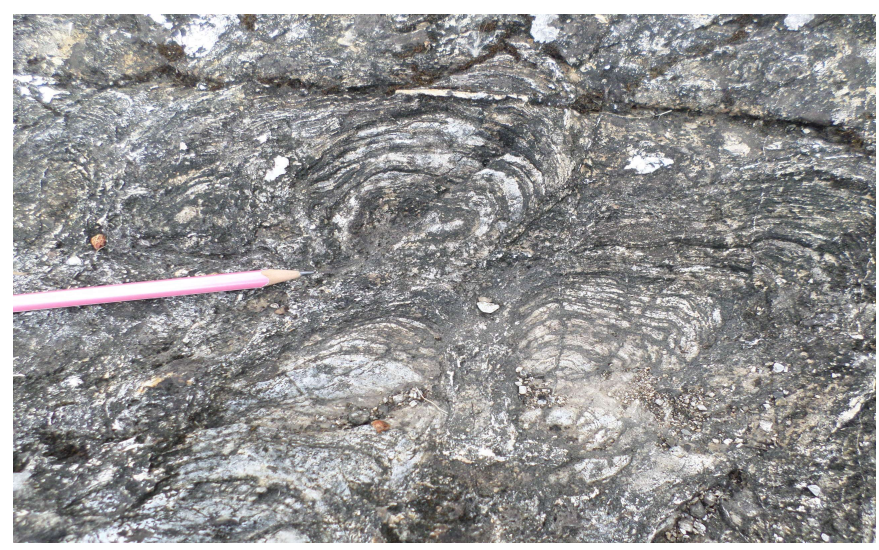

Fig. 6: Columnar stromatolites observed in the rocks of the Dhading Dolomite exposed at Pamphuka Gaun (BK4, Fig. 2). Stromatolites show that the rock succession in the area is right side up (normal stratigraphic setting) 


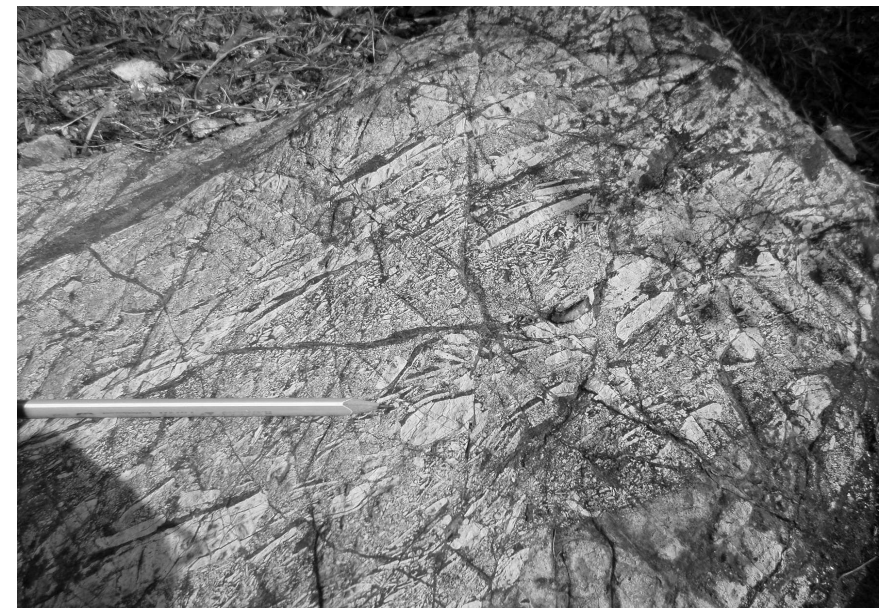

Fig. 7: Intraformational clasts seen in the dolomite of the Dhading Dolomite exposed at Pamphuka

Nawakot Group. Besides this, there are a number of local anticlinal and synclinal folds in various parts of the study area. They are best observed along the road section between Ridi to Rudrabeni area. The Ridi Khola Anticline has the low plunge while the Rimuwa-Rudrabeni Syncline has the highest plunge. There are ten remarkable regional scale folds, five synclinal folds and five anticlinal folds.

The Ridi Khola Anticline lies at the southernmost part of the study area whose axis cuts the Ridi Khola and passes through the junction of the Ridi Khola and the Kali Gandaki River and extends towards Argalli of the Palpa District. At the northern limb of this Anticline, thin-to medium-bedded calcareous slate has been observed whereas in the southern limb thinlybedded greenish grey phyllite has been mapped.

The Ridi-Karikot Syncline lies at the southernmost part of the study area about $400 \mathrm{~m}$ north from the Ridi Khola Anticline whose axis passes from the left bank of the Ridi Khola and passes through the Kali Gandaki River and extends towards Karikot in the west.

The Ruru Anticline lies about $500 \mathrm{~m}$ north from the RidiKarikot Syncline whose axis passes from the Ruru in the northwest and ends up $500 \mathrm{~m}$ east of Ridi. Along the axis of this Anticline laminated calcareous greenish grey phyllite has been observed. At the northern limb of this Anticline, boudins of quartzite were observed within the phyllite along the RidiRudrabeni road section.

The Baletaksar-Gwadi Syncline lies about $4 \mathrm{~km}$ north from the Ruru Anticline whose axis passes from the Baletaksar in the northwest and Gwadi in the southeast. Along the axis of this Syncline thinly-bedded grey phyllite has been mapped.

The Huga-Bamgha Anticline about $2.5 \mathrm{~km}$ north from the Ridi-Karikot Syncline whose axis extends from Huga in the northwest to Gwadi in the southeast and also cuts the Kali Gandaki River. The axis passes through Baunwa outlier which is composed of the rocks of the Dhading Dolomite. Along the axis of this Anticline thinly-bedded greenish grey phyllite with bands of slightly-weathered quartzite has been observed.

The Rimuwa-Rudrabeni Syncline lies at the central part of the study area about $600 \mathrm{~m}$ north from the Huga-Bamgha Anticline. Its axis of this syncline passes from the left bank of the Badi Gad Khola and passes through the junction between the Badi Gad Khola and the Kali Gandaki River at Rudradrabeni in the southeast. The axis also passes through the Dhading Dolomite at Botegaun.

The Juhan-Eksing Anticline lies about $500 \mathrm{~m}$ north from the Rimuwa-Rudrabeni Syncline whose axis passes through the right bank of the Badi Gad Khola extends from Juhan in the northwest to Aslewa in the southeast. The fold axis is parallel to the Badi Gad Khola. The axis passes through the Upper Member of the Nourpul Formation. Along the axis of this Anticline thinly-bedded purplish and greenish phyllite with quartz veins have been observed.

The Juniya-Limgha Syncline lies $600 \mathrm{~m}$ north of the Juhan-Eksingh Anticline. Its axis passes from the Turang in the northwest and Limgha in the southeast. The axis passes through the Dhading Dolomite. The axis is curved at the middle at Juniya.

The Bharse-Thaple Anticline lies about 250-600 m north from the Juniya-Limgha Syncline whose axis extends from Bharse in the northwest to Thapleko Lek in the southeast. The axis passes through the Upper Member of the Nourpul Formation and the Dhading Dolomite.

The Chiureko Syncline lies about 250 m north of the Bharse-Thaple Anticline. Its axis passes from the Dabhungau in the northwest and extends towards Thapleko Lek in the southeast. The fold axis passes through the Upper Member of the Nourpul Formation and the Dhading Dolomite. The axis is curved at the middle and runs parallel to the Bharse-Thaple Anticline.

From geological cross-sections and stereographic analyses, characteristics of folds were determined (Table 1).

\section{Harewa Khola Thrust}

The Harewa Khola Thrust is a distinct tectonic boundary separating the Dhading Dolomite with the Upper Member of the Nourpul Formation (Fig. 8). It is the only large scale thrust found in the study area. The thrust lies at the northernmost part of the study area. In this region, the thrust extends from Gwadha in the east to Harrachaur in the west. The Dhading Dolomite is at the footwall of the fault whereas the Nourpul Formation is at hanging wall. This shows the presence of fault between the two formations since dip direction of the fault is towards the older Nourpul Formation. In the study area, the thrust is about $12 \mathrm{~km}$ long. The dip of the thrust varies from 30 to $50^{\circ}$ due SW. 
Table 1: Characteristics of folds

\begin{tabular}{lcccc}
\hline \multicolumn{1}{c}{ Fold } & Amplitude (m) & Width (m) & $\begin{array}{c}\text { Trend/Plinge of fold axis } \\
\text { (degree) }\end{array}$ & $\begin{array}{c}\text { Interlimb angle } \\
\text { (degree) }\end{array}$ \\
\hline Ridi Khola Anticline & 500 & 1000 & $106 / 2$ & 100 \\
Ridi-Karikot Syncline & 200 & 1500 & $78 / 10$ & 106 \\
Ruru Anticline & 500 & 1250 & $121 / 05$ & 106 \\
Baletaksar-Gwadi Syncline & 750 & 5000 & $120 / 07$ & 110 \\
Huga-Bamgha Anticline & 500 & 1100 & $297 / 18$ & 130 \\
Rimuwa-Rudrabeni Syncline & 450 & 3000 & $293 / 31$ & 88 \\
Juhan-Eksing Anticline & 400 & 2500 & $136 / 22$ & 83 \\
Juniya-Limgha Syncline & 600 & 5000 & $298 / 05$ & 89 \\
Bharse-Thaple Anticline & 1500 & 1500 & $105 / 11$ & 104 \\
Chiureko Syncline & 600 & 2500 & $305 / 04$ & 97 \\
\hline
\end{tabular}

\section{Badi Gad Fault}

During the field work, several geological as well as geomorphic evidences of the existence of the active fault were found. These evidences include the presence of several shear zones in the area (Fig. 2). In addition to shear zones, geomorphic evidences of existence of the Badi Gad Fault like clustering of large and several landslides along a confined linear zone, river course diversion, terrace tilting, recent fault scarps, shifting of quartz veins along the strike of the beds and foliation of the rocks, etc. are recorded. The details of this study was carried out and published by Timalsina and Paudyal (2018) after this team work.

\section{Erosional structures}

There are two outliers as erosional structures in the area which are named as the Baunwa outlier and the Khadikot outlier. Both of these outliers belong to the rocks of the Dhading Dolomite surrounded by the older rocks of the Nourpul Formation. The fold axis of the Huga-Bamgha Anticline passes through the Baunwa outlier and divides it in two halves. This

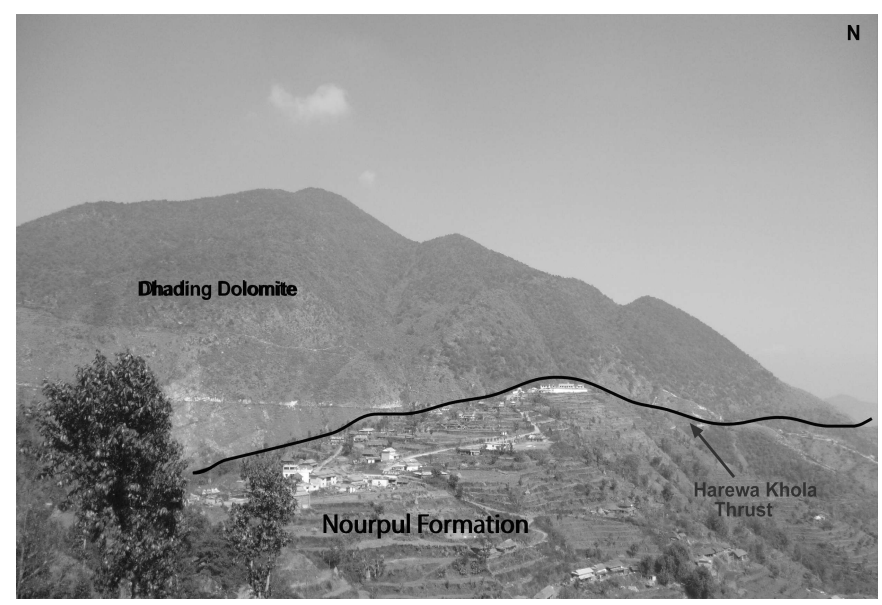

Fig. 8: Geomorphic view of the Harewa Khola Thrust outlier is about $2 \mathrm{~km}$ long and $1.5 \mathrm{~km}$ wide. Similarly, the Khadikot outlier is exposed around the village named Khadikot. This outcrop is isolated by the Upper Member of the Nourpul Formation from its main part of the Dhading Dolomite. This outlier is about $2.5 \mathrm{~km}$ long and $300 \mathrm{~m}$ wide.

\section{DISSCUSSION}

The rocks of the Nourpul Formation in the present area can be mapped under three geological units as members. They are named as the Lower Member, the Middle Member and the Upper Member of the Nourpul Formations after this work. The rocks of the Nourpul Formation in Mugling-Damauli section of west-central Nepal has even been mapped under four members and several beds (Paudyal and Paudel, 2011a, 2011b; Paudyal, 2014). This shows that the mode of deposition of the Nourpul Formation is varied laterally from central to western region of Nepal.

The Lesser Himalaya exhibits thin-skinned style of deformation and has been interpreted as a fold-and-thrust zone forming a foreland-propagating duplex structure (Schelling and Arita, 1991; Srivastava and Mitra, 1994; Decelles et al., 1998; Paudel and Arita, 2000; Paudyal 2014). The present study area also is a part of the Lesser Himalayan duplex.

The MCT is the roof thrust, which lies several kilometers north from the present study. The MBT acts as a floor thrust for the Lesser Himalayan duplex (Molnar et al., 1973; Seeber and Armbruster, 1981; Verma and Kumar, 1987, Paudyal, 2014) which is also several kilometers south from the present study. Several folds developed in the present study possibly represent presence of a large synclinorium and an anticlinorium. These folds were probably developed in the process of propagation of the horses of the thrust sheets above the Lesser Himalayan rocks in the region. The Harewa Khola Thrust is probably the imbricate fault of the region. 
A number of shear zones are identified and mapped along a certain region of the area. There are other several faultrelated indicators to explain the presence of the Badi Gad Fault in this region. The north-west extension of the presently located Badi Gad Fault ultimately joins with the fault as mapped by Nakata (1984).

Analysis of major and small-scale structures in the area shows that the Lesser Himalaya is characterized by poly-phase deformational history as in the other parts of the Lesser Himalaya such as in the eastern Nepal Himalaya (Schelling, 1989), Langtang area (Macfarlane, 1992), Pokhara-Butwal area (Paudel and Arita, 2000), and Mugling-Damauli area (Paudyal and Paudel, 2013; Paudyal, 2014). Among the five deformation phases, first two (D1 and D2) are supposed to be of preHimalayan (pre-Tertiary) time and the later three (D3, D4 and D5) are related to the Himalayan orogeny (Paudel and Arita, 2000; Paudyal and Paudel, 2013; Paudyal, 2014; Paudyal, 2018). The Himalayan deformational events can be considered as a single continuous phase of non-coaxial simple-shear progressive deformation related to thrust movements (Schelling, 1989).

The structures of the Lesser Himalaya in the present study display poly-phase deformation. The geological structures observed in the area were formed by at least three phases of deformation which are labeled as D3, D4 and D5, respectively. Structures having the same geometric style in all the tectonic units are assigned to the same deformational event. The deformation phase D3 is represented by the Harewa Khola Thrust. The deformation phase D4 is represented by WNWESE trending major folds in the present study. The latest deformation (D5) in the area is the formation of brittle shear zones and fractures.

\section{CONCLUSIONS}

The present study shows that the area consists of rocks of the Nourpul Formation and Dhading Dolomite of the Nawakot Group of the Lesser Himalaya.

Several sets of anticlines and synclines have been mapped in the area. There are ten remarkable regional scale folds; five synclinal folds and five anticlinal folds. Although the folds in the area are not strictly periodic, they may be described as a single fold system. All the folds have asymmetrical profiles and are plunging at an angle between $2^{\circ}$ to $31^{\circ}$. The development of these WNW-ESE trending major folds in the present study may be originated during the thrust propagation over the rocks of the Lesser Himalaya, supposed as the deformation event D4.

The Harewa Khola Thrust is a distinct tectonic boundary separating the Dhading Dolomite with the Upper Member of the Nourpul Formation. The dip of the thrust varies from 30 to $50^{\circ}$ due SW. The Harewa Khola Thrust is probably the imbricate fault and a part of the Lesser Himalayan duplex with the MCT and $\mathrm{MBT}$ as its roof and floor thrusts, respectively.
Two erosional structures named as the Baunwa outlier and Khadikot outlier are mapped in the region. Both the outliers consist of rocks of the Dhading Dolomite.

\section{ACKNOWLEDGEMENTS}

We are grateful to Prof. Dr. Lalu Prasad Paudel, Head of the Central Department of Geology, Tribhuvan University, for providing the necessary field equipment and laboratory facilities from the Department. Many thanks go to Prof. Dr. Santaman Rai for his fruitful comments and suggestions in the manuscript. We are thankful to Mr. Ram Sundar Pyakurel, Mr. Amar Singh Rai, Mr. Surya Shekhar Khadka, Mr. Bikash Ranabhat, Mr. Sunil Bikram Thakuri, Mr. Manish Singh Chaudhary, Mr. Kumar Timilsina and Mr. Byapak Yogal for their support in field mapping.

\section{REFERENCES}

DeCelles, P.G., Gehrels, G.E., Quade, J., Ojha, T.P., Kapp, P.A., and Upreti, B.N., 1998, Neogene foreland basin deposits, erosional unroofing, and the kinematic history of the Himalayan fold-thrust belt, western Nepal. Geological Society of America Bulletin, v. 110, pp. 2- 21.

$\mathrm{https}: / / \mathrm{doi} .0 \mathrm{rg} / 10.1130 / 0016-$ $7606(1998) 110<0002$ :NFBDEU $>2.3 . \mathrm{CO} ; 2$

Dewey, J.F. and Bird, J.M., 1970, Mountain belts and new global tectonics. Journal of Geophysical Research, v. 75, pp. 2625-2685.

https://doi.org/10.1029/JB075i014p02625

Dhital, M.R. and Kizaki, K., 1987a, Structural aspect of the Northern Dang, Lesser Himalaya. Bulletin of the College of Science, University of Ryukyus, Okinawa, v. 45, pp. 159-182.

Dhital, M.R. and Kizaki, K., 1987b, Lithology and stratigraphy of the Northern Dang, Lesser Himalaya. Bulletin of the College of Science, University of Ryukyus, Okinawa, v. 45, pp. 183-244.

Dhital, M.R., Thapa, P.B., and Ando, H., 2002. Geology of the inner Lesser Himalaya between Kusma and Syangja in western Nepal. Bulletin of the Department of Geology, Tribhuvan University, Kathmandu, Nepal, v. 9, Special Issue, pp. 1-60.

Gansser, A., 1964, Geology of the Himalayas .Interscience Publisher, London. 289p.

Macfarlane, A.M., 1992, Chronology of the tectonic events in the crystalline core of the Himalaya, Langtang National Park, central Nepal. Tectonics, v. 12, pp. 1004-1025.

https://doi.org/10.1029/93TC00916

Molnar, P., Fitch, T.J., and Wu, F.T., 1973, Fault plane solutions of shallow earthquakes and contemporary tectonics in Asia. Earth and Planetary Science Letters, v. 19 pp. 101112. 
https://doi.org/10.1016/0012-821X(73)90104-0

Nakata, T., 1982, A photogrametric study on active faults in the Nepal Himalayas. Journal of Nepal Geological Society, v. 2, Special Issue, pp. 67-80.

Nakata, T., Iwata, S., Yamanaka, H., Yagi, H., and Maemoku, H., 1984, Tectonic Landforms of several Active Faults in the Western Nepal Himalayas. Journal of Nepal Geological Society, v. 4, Special Issue, pp. 177-200.

Paudel, L.P. and Arita, K., 2000, Tectonic and polymetamorphic history of the Lesser Himalaya in central Nepal. Journal of Asian Earth Sciences, v. 18, pp. 561-584.

https://doi.org/10.1016/S1367-9120(99)00069-3

Paudyal, K.R. and Paudel, L.P., 2011a. Geological setting and lithostratigraphy of the Lesser Himalaya in the MuglingBanspani area, central Nepal. Journal of Nepal Geological Society, v. 42, pp. 51-64.

Paudyal, K.R. and Paudel, L.P., 2011b, Re-interpretation of the stratigraphy of the Nawakot Complex in the Mugling area between Dasdhunga and Ghumaune, central Nepal. Journal of Stratigrahic Association of Nepal, v. 7, pp. 23-32.

Paudyal, K.R., 2012, Depositional environment of the Lesser Himalayan rocks in the Mugling-Bandipur area, central Nepal. Journal of Nepal Geological Society, v. 44, pp. 89-98.

Paudyal, K.R. and Paudel, L.P., 2013, Geological study and root zone interpretation of the Kahun Klippe, Tanahun, and central Nepal. Himalayan Geology, v. 34, No. 2, pp. 93-106

Paudyal, K.R., 2014, Geological and Petrological Evolution of the Lesser Himalaya between Muling and Damauli, central Nepal. A Dissertation for the Award of Doctor of Philosopy (Ph. D.) Degree in Geology submitted to the Central Department of Geology, Institute of Science and Technology, Tribhuvan University, Nepal, Unpublished, $252 \mathrm{p}$.

Paudyal, K.R., 2018, Thin skinned tectonics and deformation history of Lesser Himalaya of Nepal: study from MuglingDamauli area. Journal of Academic Research (University Campus, Tribhuvan University), v. 1, pp. 23-28.

Powell, C.M. and Conaghan, P.J., 1973, Platetectonics and the Himalayas. Earth Planetary Science Letters, v. 20, pp. 1-12. https://doi.org/10.1016/0012-821X(73)90134-9

Sakai, H., 1983, Geology of the Tansen Group of the Lesser Himalaya in Nepal. Memoirs of the Faculty of Science, Kyushu University (Japan), Series D, Geology, v. 25, pp. 27-74.

Sakai, H., 1985, Geology of the Kali GandakiSupergroup of the Lesser Himalaya in Nepal. Memoirs of the Faculty of Science, Kyushu University (Japan), Series D, Geology, v. 25, pp. 337-397.

Sako, S., Ishida T., and Ohta, Y., 1973, Dhaulagiri Region. In: Geology of the Nepal Himalayas, Ohta, Y. and Akiba, Ch.
(Eds.), Hashimoto, S. (Supervisor), Himalayan Committee of Hokkaido University, Saikon Publishers, Tokyo, pp. 189-211.

Schelling, D. and Arita, K., 1991, Thrust tectonics, crustal shortening, and the structure of the far-eastern Nepal Himalaya. Tectonics, v. 10, pp. 851-862.

https://doi.org/10.1029/91TC01011

Schelling, D., 1989, The geology of the Rolwaling and the eastern Nepal Himalaya. A PhD thesis submitted to the Faculty of the Graduate School of the University of Colorado, USA, 512p.

Seeber, L. and Armbruster, J.G., 1981, Great detachment earthquakes along the Himalayan arc and long-term forecasting. In: Ewing, M. (Ed.), Earthquake Prediction: An International Review, American Geophysical Union, Series, v. 4, pp. 259-277.

$$
\text { https://doi.org/10.1029/ME004p0259 }
$$

Shrestha, J.N., Pradhananga, U.B., and Pradhan, P.M., 2000, Geological map of parts of Palpa, Syangja and Gulmi Districts, Sheet No. 2783 03(63M/9) (1:50,000). Department of Mines and Geology, Kathmandu.

Stöcklin, J., 1980, Geology of the Nepal and its regional frame. Journal of Geological Society of London, v. 137, pp. 1-34. https://doi.org/10.1144/gsjgs.137.1.0001

Stöcklin, J. and Bhattarai, K.D., 1977, Geology of Kathmandu Area and Central Mahabharat Range Nepal. Department of Mines and Geology, Kathmandu, Nepal, 86p.

Srivastava, P. and Mitra, G., 1994, Thrust geometries and deep structure of the out and Lesser Himalaya, Kumaon and Garhwal (India): Implication for evolution of the Himalayan fold and-thrust belt. Tectonics, v. 13, pp. 89109. https://doi.org/10.1029/93TC01130

Tater, J.M., Shrestha, S.B., and Shrestha, J.N., 1983, Geological map of Western Central Nepal, Scale: 1:250,000. Department of Mines and Geology, Kathmandu.

Timalsina, K. and Paudyal, K.R., 2018, Fault-controlled geomorphic features in Ridi-Shantipur area of Gulmi District and their implications for active tectonics. Journal of Nepal Geological Society, v. 55 (Sp. Issue), pp. 157165. https://doi.org/10.3126/jngs.v55i1.22807

Upreti, B.N. and Le Fort, P., 1999, Lesser Himalayan crystalline nappes of Nepal: problems of their origin. Geological Society of America Special Paper, v. 328, pp. 225-238.

https://doi.org/10.1130/0-8137-2328-0.225Verma, R.K. and Kumar, G.V.R.K., 1987, Seismicity and the nature of plate movement along the Himalayan arc, northeast India and Arakan-Yoma: a review. Tectonophysics, v. 147, pp. 59-70. 